\title{
PHYSICAL PROPERTIES OF EGYPTIAN ARTICHOKE HEADS "KHARSHOOF"
}

\section{Soliman Nassif $^{1}$ Hussien Elsoury ${ }^{2}$ Azhar El-Werch ${ }^{2}$}

\section{ABSTRACT}

Artichoke physical properties studies are very important as design parameters for each of handling, sorting and packing applications. Some physical characteristics and mechanical properties of the local artichoke cultivar (Balady) were investigated directly after harvesting at a moisture content of about $86.17 \%$ (wet basis). The physical characteristic include equatorial diameters, height, single bud volume, surface area and weight, spheresty, particle density, bulk density and porosity. The mechanical properties include the parameters of stress-strain radial compression test as bio-modulus of elasticity, bio-yield force, yield stress and strain, and biorupture stress and strain. The results showed that the artichoke buds which were under study had diameter range from 46.455 to $112.64 \mathrm{~mm}$, height between 61.83 to $128.26 \mathrm{~mm}$, volume from 76.00 (10 -6 m3) to 897.75 (10 -6 $\mathrm{m3})$, surface area between 92.285 (10 -4 m2) to 384.307 (10 -4 m2), weight between 44 to $463.92(\mathrm{~g})$, particle density between 441 to $696 \mathrm{~kg} / \mathrm{m3}$, and bulk density between 167.00 to 196.26 with an average equal to 179.84 $\mathrm{kg} / \mathrm{m3}$, spheresty between 0.738 to 0.995 and porosity between $59.28 \%$ to $74.19 \%$.

The mechanical properties of artichoke bud were determined under radial compression test in terms of initial bio modulus of elasticity, secondary bio modulus of elasticity, bio yield stress, bio yield strain, bio yield energy, bio rupture stress, bio rupture strain; and bio rupture energy. The mean value of initial bio modulus of elasticity (7.121 MPa), secondary bio modulus of elasticity (8.350 MPa), bio yield stress (0.351 MPa), bio yield strain (0.051), bio yield energy $(0.298 \mathrm{N.m})$, bio rupture stress (2.352 MPa), bio rupture strain (0.485); and bio rupture energy (12.525 N.m).

1- Prof. of Food Engineering, Faculty of Agriculture, Alexandria Univ.

2- Researcher at Agricultural Engineering Research Institute, Agricultural Research Center, Ministry of Agriculture, Egypt. 
The stress-strain parameters at $10 \%$ strain as a nondestructive test were determined for each artichoke head. The stress and deformation energy ranged from 0.175 to $0.526 \mathrm{MPa}$ and from 0.060 to $0.302 \mathrm{~N} . \mathrm{m}$. respectively, with the corresponding displacement range from 1.819 to $4.646 \mathrm{~mm}$ for the artichoke head under study.

\section{INTRODUCTION}

rtichoke is one of the oldest cultivated plants. Its image is found
on ancient Egyptian tablets (URAC, 2005; Brand, 1990). The
artichoke belongs to the Compositae (sunflower) family, and is classified as a thistle. It is grown for its round or conical flower heads, which are harvested in the green immature stage. The globe artichoke is commonly a perennial, cool-season vegetable that yields and produces best when grown where cool to mild climates prevail. Artichokes (globe) are flowers buds and can be grown from seed or from crown shoots. However, Egyptian growers prefer the crown shoots from the green globe variety for their higher yields. These shoots are obtained from root sections attached to the basal stems, often referred to as stumps.

Due to the lack of homogeneity in seed-propagated populations, artichoke varieties traditionally have been composed of a single clone or a group of phenotypically similar clones. These varieties are propagated vegetatively to maintain the genetic consistency needed to assure uniformity among artichoke buds. A high degree of uniformity is needed for the artichoke to be commercially acceptable.

Egypt is the fourth largest producer which produces about 4.9 percent of the world production (Carlo, 2001; Peter 1998). Al-Bohaira governorate is famous by the production of artichoke and represents the most suitable climate its production all over the world especially KafrEldawar region. Total cultivated area in Kafr-Eldwar region was 5774 feddan in season 2000/2001; average yield is 7.8 tons per feddan, about 25807 heads per feddan (kenanaonline, 2007).

The total cultivated area in Egypt is about 9476 ha (22562 feddan), producing about 202458 tons of artichoke heads (FAO, 2012).

There is highly demand about artichoke in the world markets. Although, recently there has been an increasing demand for artichokes exporting 
from Egypt, it was realized lake of information about its physical properties studies. Tremendous attention must be paid to increase vegetable production, especially globe artichokes in Egypt.

The artichoke heart (the bottom portion of the trimmed artichoke) is considered a delicacy (Artichoke World production, 2001).

Artichoke buds are harvested when reach $6 \mathrm{~cm}$ to $10 \mathrm{~cm}$ in diameter and the petals still tight by cutting the stem about $7.5 \mathrm{~cm}$ below the base of the bud and are collected in sacks, boxes, or into bulk containers. Harvested buds are taken as soon as possible to packing sheds for grading and packing the same day.

Table(1): Annual production of artichoke in Egypt 2005-2011*.

\begin{tabular}{|c|c|c|c|}
\hline & & & \\
\hline Year & Area Harvested & Production & Yield \\
\hline 2011 & $\mathrm{Ha}$ & tones & $\mathrm{Hg} / \mathrm{Ha}$ \\
\hline 2010 & 9476 & 202458 & 213653.44 \\
\hline 2009 & 8909 & 215534 & 241928.39 \\
\hline 2008 & 8401 & 209614 & 249510.77 \\
\hline 2007 & 7661 & 176372 & 230220.6 \\
\hline 2006 & 8001 & 172701 & 215849.27 \\
\hline 2005 & 6500 & 140000 & 215384.62 \\
\hline
\end{tabular}

* Source: FAO (2012).

Handle buds as carefully as possible during harvest to prevent bruising, scratching, and splitting of the bracts. Use care in all sorting, grading and packing operations, to prevent damage to the buds. Artichokes are sorted and packed into containers by size count. Large sizes are generally packed 20, 24, 30, and 36 buds to the box. Medium sizes range from 42 to 54 buds per box and the smaller sizes are packed 60 or more per box (William et al., 2007).

The artichoke grows to a height more than 1 meter and wide; produces a large, violet-green flower head. The flower petals and fleshy flower bottoms are eaten as a vegetable throughout the world, was used as a food and medicine by the ancient Egyptians, Greeks, and Romans (Leslie, 2005). 
The standard which defined the quality requirements of artichokes (to be supplied fresh to the consumers) at the export control stage, after preparation and packaging is regulated by the U. N., Economic and Social Council (U. N., 2003).

Artichokes are classified in three classes; extra class (I) which must be of superior quality, free from defects, the central bracts must be well closed. Class (II) which must be of good quality, the central bracts must be well closed, slight defects may be allowed (defect in shape, slight deterioration due to frost and very slight bruising. Class (III) which includes artichokes doesn't qualify for inclusion in the higher classes but satisfy the minimum requirements; they may be slightly open. The following defects may be allowed are defects in shape, slight bruising, slight staining on the outer bracts and incipient woodiness of the ducts in the base.

Size is determined by the maximum diameter of the equatorial section of the head. In all classes, the artichoke must be intact, clean, fresh in appearance, free of pests, damage caused by pests, abnormal external moisture and any foreign smell or taste. The artichoke buds are size classified based on diameters into six groups, diameter of $\geq 13 \mathrm{~cm}$, diameter from $11 \mathrm{~cm}$ up to $<13 \mathrm{~cm}$, diameter from $9 \mathrm{~cm}$ up to $<11 \mathrm{~cm}$, diameter from $7.5 \mathrm{~cm}$ up to $<9 \mathrm{~cm}$, diameter from $6 \mathrm{~cm}$ up to $<7.5 \mathrm{in}$ addition a diameter from $3.5 \mathrm{~cm}$ up to $<6 \mathrm{~cm}$. (U. N., Economic and Social Council, 2003).

At present, the sorting process to meet the exporting standard is done manually. This step is high cost, labor intensive and must be performed quickly to reduce quality loss. Therefore, the sorting machine is required. In order to design and develop suitable machine, physical properties of artichoke are necessary. However, the information of these properties has not been available. Therefore, the objective of this study is to investigate the physical properties of artichoke and to propose the application of these properties for artichoke handling, processing and packing.

\section{MATERIALS AND METHODS}

Artichoke samples were picked from the farmer field in Maroon village, Sedi-Gazy, Kafr-Eldwar, Al-Bohaira Governorate, Egypt. The total of 100 Artichoke heads were picked manually every week during the 
harvesting season from February to April 2011 and carefully brought to the laboratory of physical properties at Agriculture Engineering Department Alexandria University. The measurements of physical characteristics including physical dimensions, head weight, particle density, bulk density, and sphericity were conducted. The mechanical properties of head obtained by compression stress strain test including initial and secondary modulus of elasticity, bio yield stress, bio yield energy, rupture stress and rupture energy were evaluated for each head directly after preparation for test in the same day of harvesting.

\subsection{Head Dimensions and Weight:}

The total number of 1200 heads was measured for physical dimensions evaluation (equatorial section diameters D1 and D2, top diameter D3 and height $\mathrm{H}, \mathrm{mm}$ ) using digital slide caliper model MAX-CAL made in Japan with an accuracy of $0.01 \mathrm{~mm}$. The equivalent diameter of Artichoke head (DP, mm) was calculated through the following expression (Mohsenin, 1986).

$$
D_{p}=\left(H\left(\frac{D_{1}+D_{2}}{2}\right)^{2}\right)^{\frac{1}{3}}
$$

Electronic weighing balance model Acclab LT 3200 with maximum scale of 3200 grams and with accuracy of 0.01 gram was used for heads weighing. Hundred heads were measured weekly during the harvesting season.

\subsection{Head Surface Area:}

The measurements of head surface area (without stem) were done by carefully coating the head with thin wax film. The wax covered was carefully removed from the head with special cutter, and the parts of wax was collected together on a paper and traced by $0.5 \mathrm{~mm}$ pencil and the area of traced wax was measured with planimeter (Mohsenin, 1986)

The measured surface areas were compared with the calculated surface area based on the geometric equation which assumption that the Artichoke surface area can be similar to a semi sphere and a frustum of right circular cone as the following:

Surface Area $=$ Semi Sphere + Frustum of Right Circular Cone 


$$
S=\frac{\pi}{2}\left(\frac{D_{1}}{10}\right)^{2}+\pi\left(\frac{D_{2}+D_{3}}{20}\right)\left[\left(\frac{D_{2}-D_{3}}{20}\right)^{2}+\left(\frac{H}{10}-\frac{D_{1}}{20}\right)^{2}\right]^{0.5}
$$

\subsection{Head Volume:}

The measurements of head volume (without stem) were done using platform scale technique (Mohsenin, 1986). The head carefully coated by thin film of polyethylene sheet, and weighed under water by dipping the covered head just under the water surface in a beaker (using a thin glass rod) on the electronic balance; it was evaluated in $\mathrm{cm}^{3}$ equally to the sample weight in water in grams.

The volume of Artichoke can also be calculated as a sphere using the average diameter or as the geometric shape similar to a semi sphere and a frustum of right circular cone by the following equation:

Average Volume $=$ Semi Sphere + Frustum of Right Circular Cone

$$
V=\frac{\pi}{12}\left(D_{1}\right)^{3}+\frac{\pi}{30}\left(H-\frac{D_{1}}{2}\right)\left(\left(\frac{D_{2}}{20}\right)^{2}+\left(\frac{D_{3}}{20}\right)^{2}+\frac{D_{2} D_{3}}{400}\right)
$$

\subsection{Particle density:}

The particle density $\left(\rho_{p}, \mathrm{~kg} / \mathrm{m}^{3}\right)$ was calculated using the ratio between measured head weight and head volume by the following formula:

$$
\text { Particldensity }\left(\rho_{0}, \mathrm{~kg} / \mathrm{m}^{3}\right)=\frac{\text { Head weight in air }(\mathrm{kg})}{\text { Head volume }\left(\mathrm{m}^{3}\right)}
$$

\section{Sphericity:}

The sphericity $(\Phi)$ of Artichoke expresses the characteristics shape of a head and was determined as the ratio between head measured volume and the volume of circumscribed sphere as mentioned by (Mohsenin, 1986)

Spherisity $(\Phi)=\left(\frac{\text { Head Volume }}{\text { Volume of Circumscribed Sphere }}\right)^{\frac{1}{3}}$

\subsection{Bulk density:}

The bulk density $\left(\rho_{B}, \mathrm{~kg} / \mathrm{m}^{3}\right.$ )of artichoke heads (without stems) was measured using a specific cubic wooden container with inside dimension of $50 \mathrm{~cm}$. The empty box weight was determined using an electronic scale model Terraillon ST600, with maximum capacity of 150 kilograms and accuracy of 0.01 kilograms. The box was then filled with artichokes, 
carefully in an alternative layer until reached specific height near the upper edges of it. The aberrant occupied volume was calculated. The box was lift and weighed again. The net weight of artichoke heads required to fill the box was determined. The bulk density was calculated by the following formula:

$$
\text { Bulk density } \left.\rho_{B}, \mathrm{~kg} / \mathrm{m}^{3}\right)=\frac{\text { Heads weight in the container }(\mathrm{kg})}{\text { Occupied volum }\left(\mathrm{m}^{3}\right)}
$$

\subsection{Porosity:}

The porosity $(\boldsymbol{P})$ is the percentage of air between the heads compared to a bulk volume of Artichoke which is referred to as packing factor, may be calculated from the following relationship (Mohsenin, 1986) as:

$$
\boldsymbol{P}=\frac{\rho_{p}-\rho_{B}}{\rho_{p}}
$$

\subsection{Moisture content:}

The moisture content, wet base $\%$ was determined using natural convection oven dryer model (WS-3). Samples were cut into thin slices axially of $5 \mathrm{~mm}$ thick. The weighed samples were placed in a single layer in Petri dishes and dried at $105 \pm 1{ }^{\circ} \mathrm{C}$ for 24 hours according to Ghadge et al 1989. After drying was completed, the sample dishes were kept in desiccators to attain room temperature, after which they were weighed for dry mass and the moisture content were evaluated.

\subsection{Stress-Strain Test}

The stress-strain tests were carried out by using Cole Parmer Instron machine model (G-08232-28) as shown in figure (1). The tests in this study were carried out at crosshead speed of $20 \mathrm{~mm} / \mathrm{min}$.

Lateral compression stress-strain test was run on 25 artichoke heads weekly randomly selected, directly after harvesting, by placing a whole artichoke head laterally on the lower plate between the two parallel plungers with $2 \mathrm{~cm}$ diameter for each. The lower plunger was then moved up gradually till the bottom of the upper plunger just has touched the top surface of the sample without significant loading effect. The force was applied on the upper plunger by the press crosshead which was moved down at the selected speed $(20 \mathrm{~mm} / \mathrm{min})$, deforming the sample 
until the failure was achieved. The deformation of the sample under the press was considered equal to the change in the sample thickness.

For stress-strain tests, the initial modulus of elasticity was calculated as the initial slope of the stress-strain curve before straight line. While, the modulus of elasticity was calculated as the slope of the stress-strain curve at the stage appear to be straight line. Failure energy was calculated as the area under the stress-strain curve until rupture point.

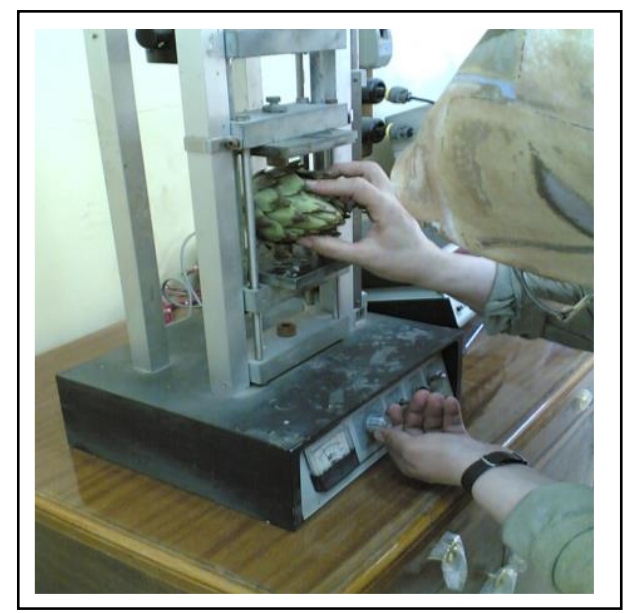

Figure (1): The Stress -Strain tests using an Instron Machine Cole Parmer model (G-08232-28).

\section{RESULTS AND DISCUSSION}

\subsection{Physical Characteristics}

The total of 1200 heads of Artichoke samples (100 heads weekly during the harvesting season) were prepared for measurements of physical dimensions directly after harvesting. The heads were numerically marked and the two equatorial diameters, top diameter, height, weight, surface area and volume were measured.

The statistical descriptive parameters of the different measured and calculated physical characteristic parameters of fresh Artichokes were shown in table (2).

The frequency distribution curves of 1200 artichoke heads percentage include head mass, volume, average diameter, surface area and height of the samples was illustrated in figure (2). 


\subsubsection{Artichoke mass}

The individual bud weight of fresh artichoke samples was measured. The results varied through a wide range of $419.92 \mathrm{~g}$., with a maximum value of $463.92 \mathrm{~g}$., and minimum value $44.00 \mathrm{~g}$., and with an average of 158.06 g., standard error of 2.64 and standard deviation of 69.01. Figure (2) clearly shows the normal distribution curve for artichoke mass.

\section{Table (2) Descriptive statistics analysis of physical characteristic}

\section{data of Artichoke}

\begin{tabular}{|c|c|c|c|c|c|c|c|c|}
\hline Parameter & $\begin{array}{c}\text { bud } \\
\text { weight } \\
\text { g. }\end{array}$ & \begin{tabular}{|c|} 
max. \\
$\begin{array}{c}\text { Diameter D1, } \\
\mathrm{mm} .\end{array}$
\end{tabular} & $\begin{array}{c}\text { Min. } \\
\text { Diameter } \\
\text { D2, mm. }\end{array}$ & $\begin{array}{c}\text { Top } \\
\text { Diameter } \\
\text { D3, mm. }\end{array}$ & $\begin{array}{c}\text { average } \\
\text { Diameter } \\
\mathrm{D}, \mathrm{mm} .\end{array}$ & $\begin{array}{l}\text { Height H, } \\
\text { mm. }\end{array}$ & $\begin{array}{l}\text { Arithmatic } \\
\text { diam, mm. }\end{array}$ & $\begin{array}{l}\text { Geometric } \\
\text { Diam, mm. }\end{array}$ \\
\hline Mean & 158.06 & 73.00 & 71.56 & 57.25 & \begin{tabular}{|l|}
72.28 \\
\end{tabular} & 87.47 & 77.34 & 76.92 \\
\hline Standard Error & 2.64 & 0.43 & 0.43 & 0.35 & 0.43 & 0.47 & 0.42 & 0.42 \\
\hline Median & 143.55 & 71.82 & 70.27 & 56.22 & 70.98 & 86.00 & 76.37 & 75.99 \\
\hline Mode & 136.99 & 64.60 & 72.45 & 57.96 & 74.36 & 94.60 & 72.90 & 79.90 \\
\hline Standard Deviation & 69.01 & 11.16 & 11.30 & 9.04 & 11.20 & 12.36 & 10.86 & 10.87 \\
\hline Range & 419.92 & 66.19 & 66.27 & 53.02 & 66.23 & 66.43 & 57.48 & 58.20 \\
\hline Minimum & 44.00 & 46.46 & 45.60 & 36.48 & 46.03 & 61.83 & 53.58 & 52.60 \\
\hline Maximum & 463.92 & 112.64 & 111.87 & 89.50 & 112.26 & 128.26 & 111.06 & 110.80 \\
\hline Count & 1200.00 & 1200.00 & 1200.00 & 1200.00 & 1200.00 & 1200.00 & 1200.00 & 1200.00 \\
\hline Confidence Level(95.0\%) & 5.18 & 0.84 & 0.85 & 0.68 & 0.84 & 0.93 & 0.82 & 0.82 \\
\hline Parameter & $\begin{array}{c}\text { Volume, } \\
\mathrm{cm}^{3}\end{array}$ & $\begin{array}{c}\text { Sphere } \\
\text { Volume, } \mathrm{cm}^{3}\end{array}$ & $\begin{array}{c}\text { Conical } \\
\text { volume, } \mathrm{cm}^{3}\end{array}$ & $\begin{array}{l}\text { Surface } \\
\text { Area, } \mathrm{cm}^{2}\end{array}$ & $\begin{array}{c}\text { particle } \\
\text { density, } \\
\text { g/cm }\end{array}$ & Sphericity $\%$ & $\begin{array}{c}\text { Volume of } \\
\text { Circumscri } \\
\text { bed sphere, } \\
\mathrm{cm}^{3}\end{array}$ & Porosity\% \\
\hline Mean & 274.83 & 253.05 & 283.75 & 191.04 & 0.56 & 0.914 & 373.35 & 67.67 \\
\hline Standard Error & 5.45 & 4.27 & 4.77 & 2.05 & 0.00 & 0.002 & 6.34 & 0.09 \\
\hline Median & 236.10 & 229.95 & 257.67 & 182.79 & 0.55 & 0.918 & 332.87 & 67.56 \\
\hline Mode & 303.24 & 267.21 & 300.00 & 201.58 & 0.56 & 0.924 & 381.26 & 67.84 \\
\hline Standard Deviation & 142.46 & 111.63 & 124.71 & 53.68 & 0.04 & 0.058 & 165.84 & 2.48 \\
\hline Range & 821.75 & 636.25 & 712.36 & 292.02 & 0.25 & 0.226 & 975.21 & 14.90 \\
\hline Minimum & 76.00 & 76.22 & 86.66 & 92.29 & 0.44 & 0.769 & 129.00 & 59.28 \\
\hline Maximum & 897.75 & 712.47 & 799.02 & 384.31 & 0.70 & 0.995 & 1104.21 & 74.19 \\
\hline Count & 1200.00 & 1200.00 & 1200.00 & 1200.00 & 1200.00 & 1200.000 & 1200.00 & 1200.00 \\
\hline Confidence Level(95.0\%) & 10.69 & 8.38 & 9.36 & 4.03 & 0.00 & 0.004 & 12.45 & 0.19 \\
\hline
\end{tabular}

\subsubsection{Artichoke dimensions}

The two equatorial diameters (D1, mm), (D2,mm), Top diameter $(\mathrm{D} 3, \mathrm{~mm})$ and Height $(\mathrm{H}, \mathrm{mm})$ of fresh artichoke were measured. The results of diameters varied through a wide range of $112.64 \mathrm{~mm}, 111.87$ $\mathrm{mm}$, and $89.5 \mathrm{~mm}$ and with average of $112.26 \mathrm{~mm}$ and a minimum value as $46.46 \mathrm{~mm}, 45.6 \mathrm{~mm}, 36.48 \mathrm{~mm}$ and with average $46.03 \mathrm{~mm}$, standard error of $0.43,0.43$ and .0 .35 and standard deviation 11.16, 11.30, 9.04 respectively. The result of height for fresh artichoke varied through a wide range of $66.43 \mathrm{~mm}$, with a maximum value of $128.26 \mathrm{~mm}$ and a minimum value as $61.83 \mathrm{~mm}$ and with an average of $87.47 \mathrm{~mm}$, standard error of 0.47 and standard deviation of $12.36 \mathrm{~mm}$. Figures (2) clearly 
show the normal distribution curve for average diameter and height of artichoke.

The descriptive statistical analysis of data for dimensions of artichoke of the height was presented in tables (2).

The average diameter $\left(\mathrm{D}_{\mathrm{av}}, \mathrm{mm}\right)$ and height $(\mathrm{H}, \mathrm{mm})$ of artichoke were demonstrated in figure (3).

Statistical analysis was conducted to clarify the relationship between each parameter of physical dimensions and actual initial mass of fresh artichoke. The regression analysis showed a linear dependence on

the initial mass. Therefore, the following linear regression equations were developed in order to correlate the average diameter $\left(D_{a v}, m m\right)$ and height $(\mathrm{H}, \mathrm{mm})$ of the artichoke to artichoke mass $(\mathrm{m}, \mathrm{g})$. The statistical regression artichoke equations were specified for artichoke under study as follow:

$$
\begin{aligned}
& \mathrm{D}_{\mathrm{av}}, \mathrm{mm}=47.85+0.155 \mathrm{~m} \ldots \ldots \ldots \mathrm{R}^{2}=0.906 \\
& \mathrm{H}, \mathrm{mm}=63.92+0.149 \mathrm{~m} \ldots \ldots \ldots \mathrm{R}^{2}=0.692
\end{aligned}
$$

The general trend of the measured data showed that the average diameter and height of the studied fresh artichoke directly proportion with fresh mass.

\subsubsection{Artichoke volume}

The individual volumes $\left(\mathrm{V}, \mathrm{cm}^{3}\right)$ of fresh artichoke samples were measured using water displacement technique as explained later. Figure (2) clearly show the normal distribution curve for volume of artichoke. The measured volume related to mass of the investigated artichoke were conducted and demonstrated in Figures (4) .The statistical analysis of data for the volume of artichoke was presented in tables (2).

The results were varied through a wide range of $821.75 \mathrm{~cm}^{3}$, as maximum as 897.75 and as minimum as $76.00 \mathrm{~cm}^{3}$ with an average of 274.83, standard error of 5.45, and standard deviation of 142.46 for fresh artichoke.

Linear regression statistical analysis was conducted in order to describe the relationship between artichoke volume parameter and the 

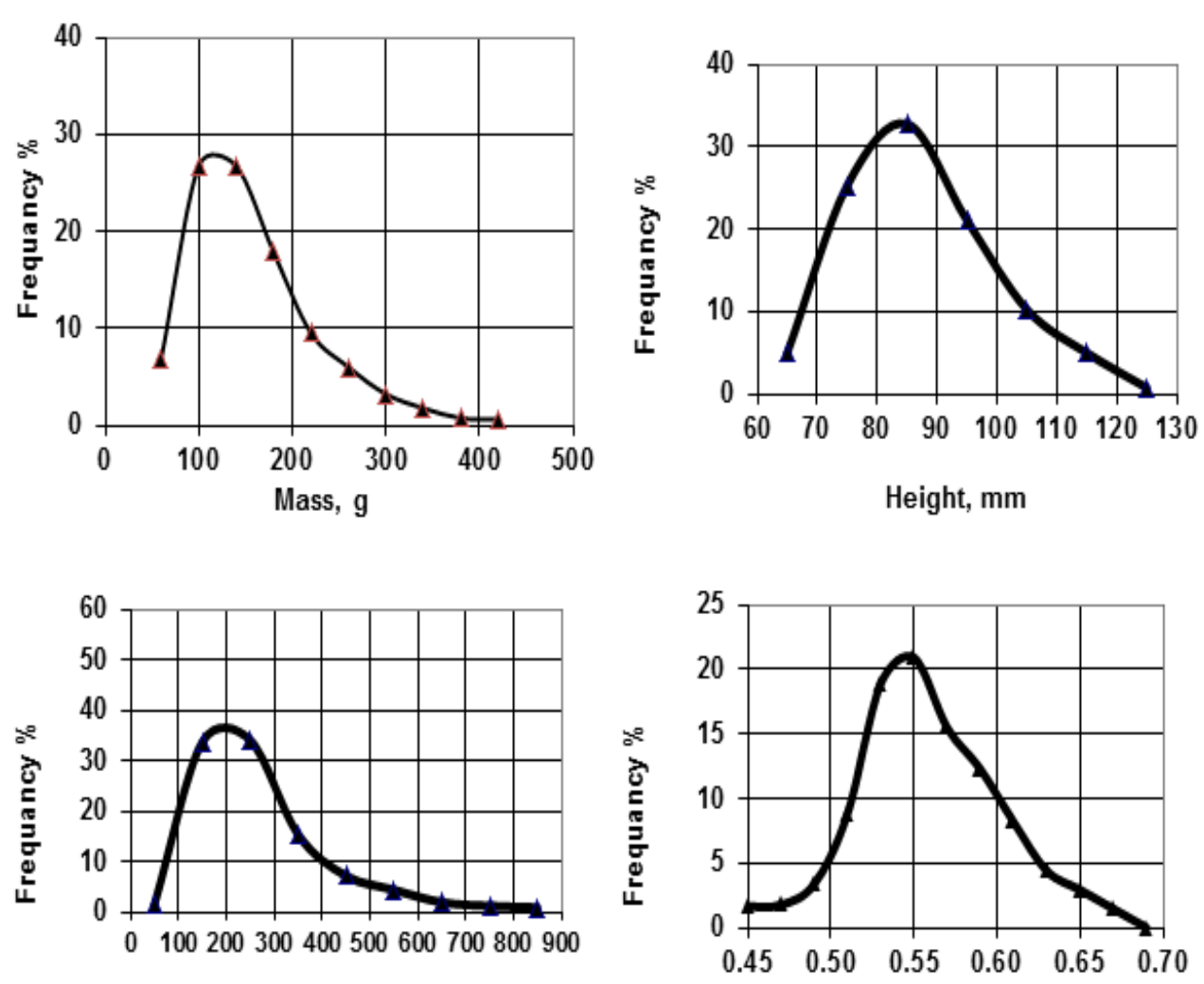

Volume, $\mathrm{cm}^{3}$

Particle Density, gm/ $\mathrm{cm}^{3}$

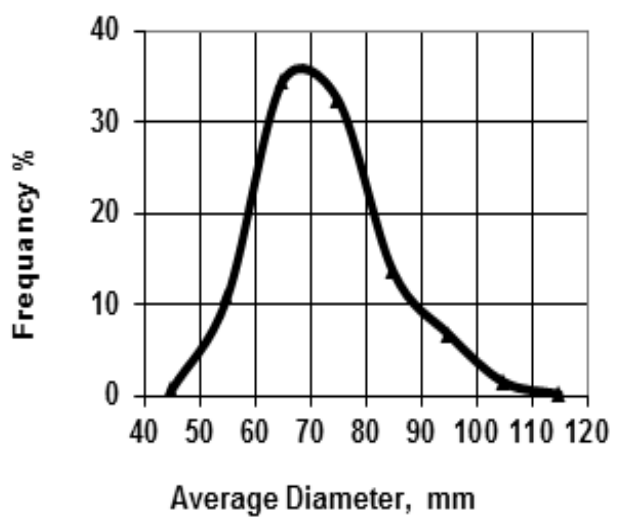

Figure (2) Artichoke frequency curve relationships for mass, measurement volume, average diameter, height and particle density 

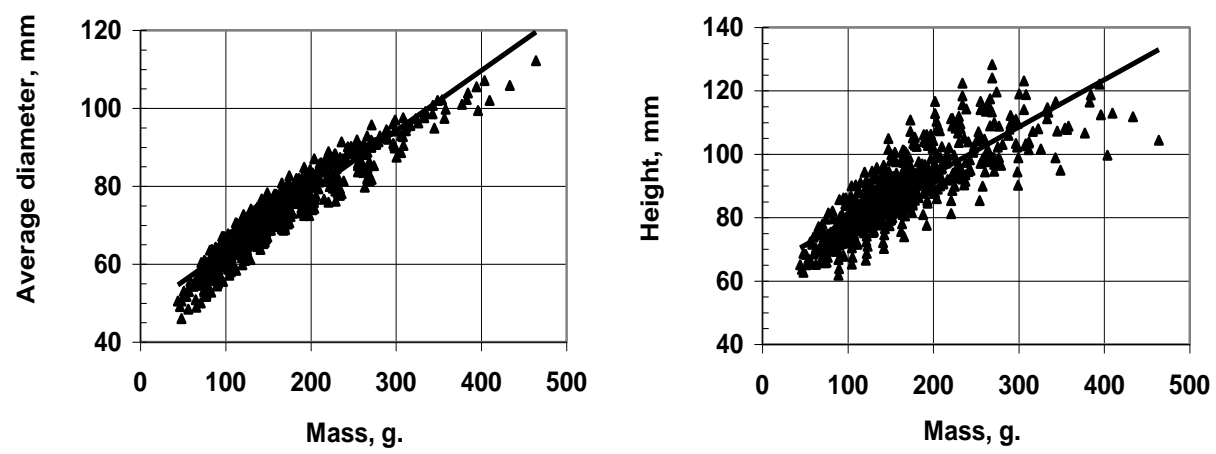

Figure (3)Fresh artichoke dimensions with mass relationship

artichoke mass $(\mathrm{m}, \mathrm{g})$. The statistical regression equation was as follow:

$$
\mathrm{V}, \mathrm{cm}^{3}=-43.953+2.0168 \mathrm{~m} \ldots \ldots . . \mathrm{R}^{2}=0.954
$$

The above equation showed that the artichoke volume for the studied fresh artichoke is directly proportions with the initial artichoke mass.

\subsubsection{Particle density}

The particle density data of fresh artichoke $\left(\rho_{\mathrm{P}}, \mathrm{kg} / \mathrm{m}^{3}\right)$ showed slightly decreased of particle density with the increasing of initial mass as demonstrated in figure (4). The particle density of artichoke was changed from $0.44 \mathrm{~g} / \mathrm{cm}^{3}$ up to $0.70 \mathrm{~g} / \mathrm{cm}^{3}$ with an average of $0.56 \mathrm{~g} / \mathrm{cm}^{3}$. Figure (2) clearly show the normal distribution curve for particle density of artichoke. The statistical regression equation was conducted in order to describe the relationship between artichoke particle density and the artichoke mass (m, g). as follow:

$$
\rho_{\mathrm{P}}, \mathrm{kg} / \mathrm{m}^{3}=649.67-0.362 \mathrm{~m} \ldots . . \mathrm{R}^{2}=0.2019 \ldots
$$

\subsubsection{Sphericity}

The sphericity of fresh artichoke were calculated according to equation (5) and demonstrated in figure (5). The sphericity values of fresh artichoke were in the range from 0.738 to 0.995 with an average of 0.892 . The data result showed randomized relationship between sphericity of fresh artichoke and initial mass as demonstrated in figure (5).

The statistical regression equation described the relationship between artichoke sphericity and mass $(\mathrm{m}, \mathrm{g})$. as follow:

$$
\Phi \%=84.195+0.0315 \mathrm{~m} \ldots . \mathrm{R}^{2}=0.124 \ldots
$$



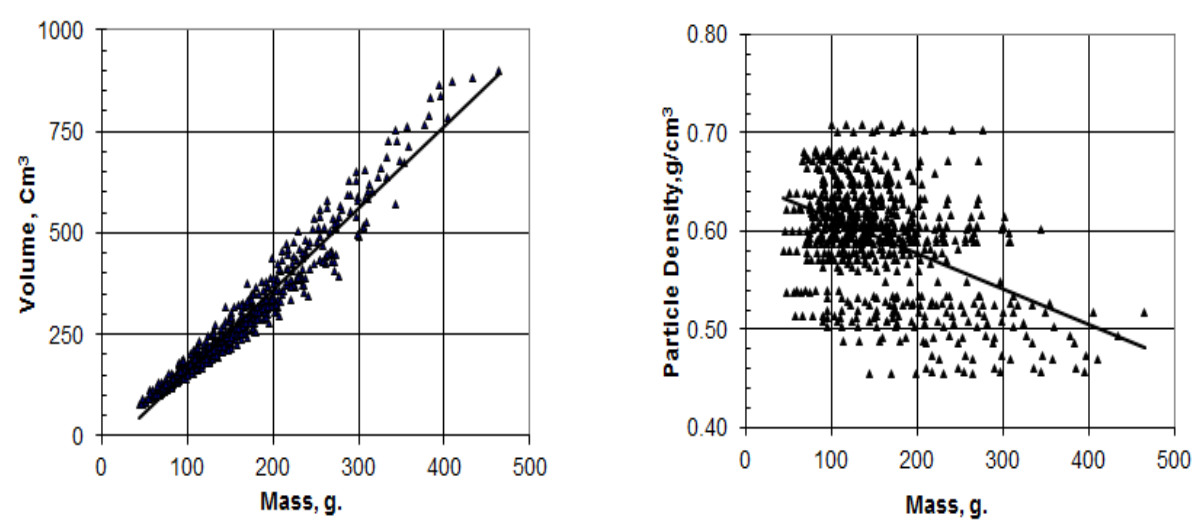

Figure (4) measurement volume and particle density fresh with mass artichoke relationship

\subsection{Surface area}

The surface area $\left(\mathrm{S}_{\mathrm{A}}, \mathrm{cm}^{2}\right)$ as a function of bud mass were demonstrated in figure (5). The results showed direct proportion between artichoke surface area and mass (m, g). These results agree with Sastry 1985.

The surface Area $\left(\mathrm{S}_{\mathrm{A}}, \mathrm{cm}^{2}\right)$ for fresh artichoke was changed from 92.29 $\mathrm{cm}^{2}$ up to $384.31 \mathrm{~cm}^{2}$ with an average $191.04 \mathrm{~cm}^{2}$ and with standard error of 2.05 and standard deviation of 53.68. Linear regression statistical analysis was conducted to correlate the surface area of fresh artichoke and bud mass $(\mathrm{m}, \mathrm{g})$. The statistical regression equations were specified for artichoke range under study as follow:

$$
\mathrm{S}_{\mathrm{A}}, \mathrm{cm}^{2}=71.267+0.7577 \mathrm{~m} \ldots \ldots \mathrm{R}^{2}=0.949
$$

\subsubsection{Porosity:}

The porosity $(\boldsymbol{P}, \%)$ of fresh artichoke were calculated and summarized in table (2). The collected data showed randomized relationship between porosity and initial mass as demonstrated in figure (5). The porosity of artichokes was changed from $59.28 \%$ up to $74.19 \%$ with an average of $67.67 \%$.

The statistical regression equation was conducted in order to describe the relationship between artichoke porosity and mass (m, g). as follow:

$$
\boldsymbol{P}, \boldsymbol{\%}=72.688-0.021 \mathrm{~m} \ldots \ldots . . \mathrm{R}^{2}=0.223 \ldots
$$



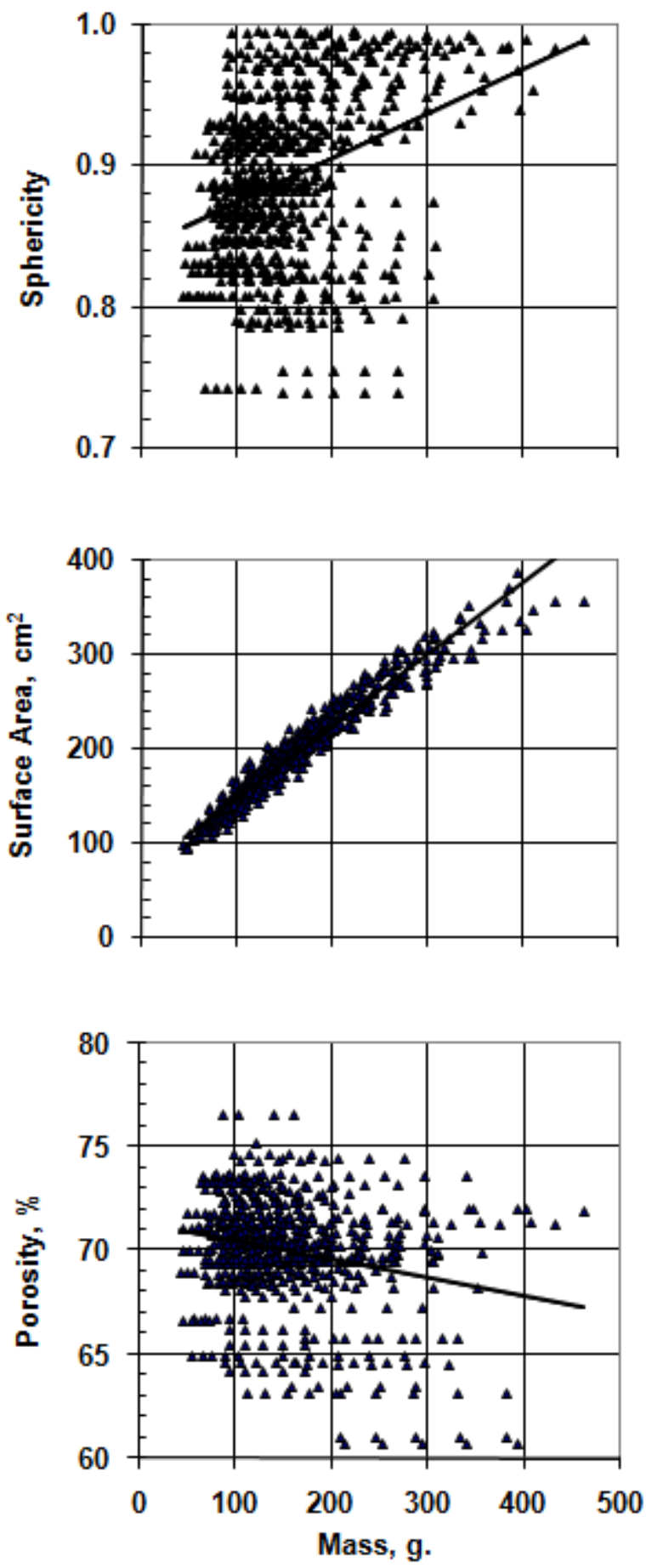

Figure (5) Sphericity, Surface area and Porosity of fresh artichoke bud 


\subsection{Mechanical properties}

\subsubsection{Stress Strain Test}

Lateral compression stress-strain test were carried out on fresh artichoke individually. Figure (6) presented the stress-strain curve of whole artichoke conducted with Instron machine when compressed between two parallel plungers each of $2 \mathrm{~cm}$ diameter and at cross head speed of $20 \mathrm{~mm} / \mathrm{min}$.

The mechanical properties of artichoke head along diagonal were determined in terms of modulus of elasticity, yield stress, yield strain, yield energy, rupture stress, rupture strain and rupture energy. The maximum, minimum and mean value of modulus of elasticity, yield stress, yield strain, yield energy, rupture stress, rupture strain and rupture energy were illustrated in table (3).

Nondestructive stress-strain test can be conducted until strain of $10 \%$ for most horticultural commodity. Stress-Strain parameters were determined at strain of $10 \%$ for each artichoke head.

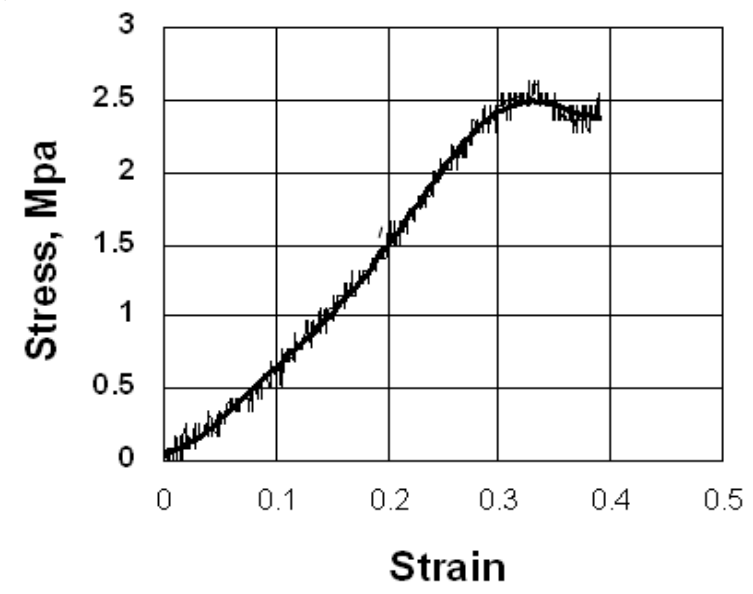

Figure (6) Typical stress strain curve of artichoke head

The minimum and maximum values of the stress and deformation energy at strain of $10 \%$ were ranged from 0.175 to $0.526 \mathrm{MPa}$ and from 0.060 to 0.302 N.m. respectively, with the corresponding displacement range from 1.819 to $4.646 \mathrm{~mm}$ for the artichoke head under study. The result of mechanical properties at $10 \%$ strain for fresh artichoke including compression stress and energy were demonstrated in figure (7) as a function of artichoke mass. 
Table (3): Mechanical Properties Of Fresh Artichoke Bud.

\begin{tabular}{|l|c|c|c|}
\hline \multicolumn{1}{|c|}{ Mechanical properties } & \multicolumn{3}{c|}{ Values } \\
\cline { 2 - 4 } & Mean & Maximum & Minimum \\
\hline Initial modulus of elasticity,(M.Pa) & 7.121 & 17.026 & 4.612 \\
\hline Secondary modulus of elasticity, (M.Pa) & 8.350 & 12.009 & 3.498 \\
\hline Yield stress, (M.Pa) & 0.351 & 0.351 & 0.351 \\
\hline Yield strain & 0.051 & 0.076 & 0.017 \\
\hline Yield energy, (N.m.) & 0.298 & 0.535 & 0.094 \\
\hline Rupture stress, (M.Pa) & 2.352 & 3.681 & 1.315 \\
\hline Rupture strain & 0.485 & 3.213 & 0.243 \\
\hline Rupture energy, (N.m.) & 12.525 & 25.286 & 5.247 \\
\hline
\end{tabular}
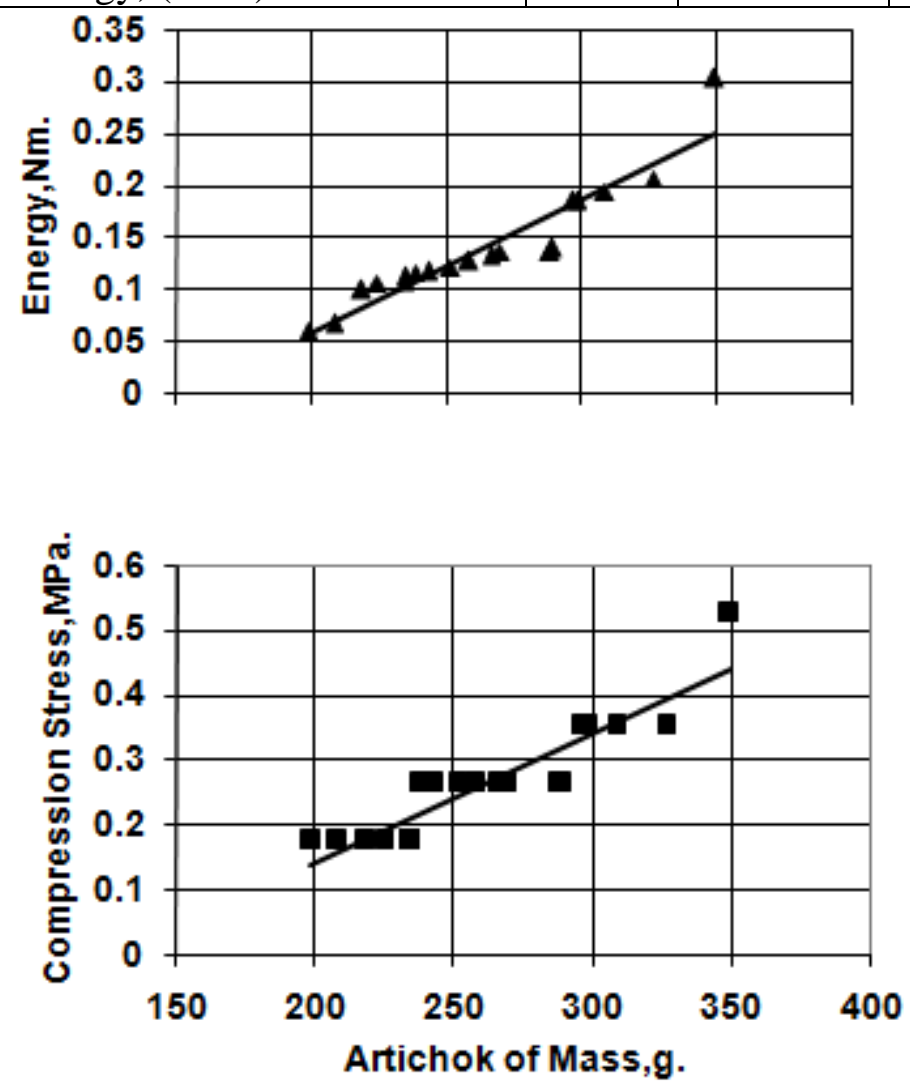

Figure (7) Compression Test at strain of $10 \%$.

Linear regression statistical analysis was conducted to correlate the energy (E, N.m.) and compression stress $\left(\sigma_{c}, \mathrm{MPa}\right)$ as a function of fresh mass $(\mathrm{m}, \mathrm{g})$. The statistical regression equations were specified for artichoke range under study as follow: 


$$
\begin{aligned}
& \mathrm{E},(\mathrm{Nm})=-0.1963+0.0013 \mathrm{~m} \ldots \ldots \ldots . \mathrm{R}^{2}=0.886 \ldots \ldots(15) \\
& \sigma_{\mathrm{c}},(\mathrm{MPa})=-0.256+0.002 \mathrm{~m} \ldots \ldots \ldots \ldots . . \mathrm{R}^{2}=0.832 \ldots \ldots(16)
\end{aligned}
$$

The general trend of the measured data showed that the energy and compression stress of the studied fresh artichoke directly proportion with initial fresh mass.

Table (3) shows that the initial and secondary mean modulus of elasticity of lateral whole fresh artichoke was 7.121 and $8.35(\mathrm{MPa})$, respectively. The variation of stress at yield point $\left(\Delta \sigma_{\mathrm{y}}, \mathrm{Pa}\right)$ was about $0.351(\mathrm{~Pa})$ with standard error of 1.96E-06 and standard deviation of 8.5E-06. The result show that the mean yield strain $\left(\varepsilon_{\mathrm{y}}\right)$ and resilience $\left(\mathrm{WD}_{\mathrm{y}}, \mathrm{Nm}\right.$.) for fresh artichoke were 0.051 and $0.298 \mathrm{Nm}$ respectively. Linear regression statistical analysis was conducted to correlate each of $\Delta$ yield Stress $(\Delta$ $\left.\sigma_{\mathrm{y}}, \mathrm{Pa}\right)$, yield strain $\left(\varepsilon_{\mathrm{y}}\right)$ and resilience $\left(\mathrm{WD}_{\mathrm{y}}, \mathrm{Nm}\right)$ of artichoke to initial fresh artichoke mass $(\mathrm{m}, \mathrm{g})$. The statistical regression equations were specified for artichoke range under study as follow:

$$
\begin{aligned}
\Delta \sigma_{\mathbf{y}}, \mathrm{Pa} & =-32.736+0.1988 \mathrm{~m} \ldots \ldots \ldots \mathrm{R}^{2}=0.917 \ldots \ldots(18) \\
\varepsilon_{\mathbf{y}} & =-0.02514+0.000289 \mathrm{~m} \ldots \ldots \mathrm{R}^{2}=0.858 \ldots .(19) \\
\mathbf{W D}_{\mathbf{y}}, \mathrm{Nm} & =-0.2188+0.001964 \mathrm{~m} \ldots . . \mathrm{R}^{2}=0.864 \ldots .(20)
\end{aligned}
$$

Rupture Stress $\left(\sigma_{\mathrm{r}}, \mathrm{MPa}\right)$ for fresh artichoke were ranged from 3.681 up to 44.694 MPa., with an average of $2.352 \mathrm{MPa}$ and standard error of 0.141 and standard deviation of 0.613 . The result show that rupture strain $\left(\varepsilon_{\mathrm{r}}\right)$ and mean toughness $\left(\mathrm{WD}_{\mathrm{r}}, \mathrm{Nm}\right.$.) for fresh artichoke were 0.485 and $12.525 \mathrm{Nm}$. respectively.

Linear regression statistical analysis was conducted to correlate the rupture stress $\left(\sigma_{\mathrm{r}}, \mathrm{MPa}\right.$.), rupture strain $\left(\varepsilon_{\mathrm{r}}\right)$ and toughness $\left(\mathrm{WD}_{\mathrm{r}}, \mathrm{Nm}\right.$.) of artichoke to initial fresh artichoke mass $(\mathrm{m}, \mathrm{g})$. The statistical regression equation were specified for artichoke range under study as follow:

$$
\begin{aligned}
\boldsymbol{\sigma}_{\mathbf{r}, \mathrm{MPa}} & =0.0143 \mathrm{~m}-1.4136 \ldots \ldots . \mathrm{R}^{2}=0.9281 \ldots(21) \\
\boldsymbol{\varepsilon}_{\mathbf{r}} & =0.0017 \mathrm{~m}-0.1188 \ldots \ldots . \mathrm{R}^{2}=0.8414 \ldots(22) \\
\mathbf{W D}_{\mathbf{r}}, \mathrm{Nm} & =0.1331 \mathrm{~m}-23.363 \ldots \ldots . \mathrm{R}^{2}=0.9324 \ldots .(23)
\end{aligned}
$$

Figures (8) and (9) represent each of yield point and rupture point of fresh artichoke as a function for initial fresh artichoke mass. The results shows that the strength of artichoke directly proportion with fresh mass. 

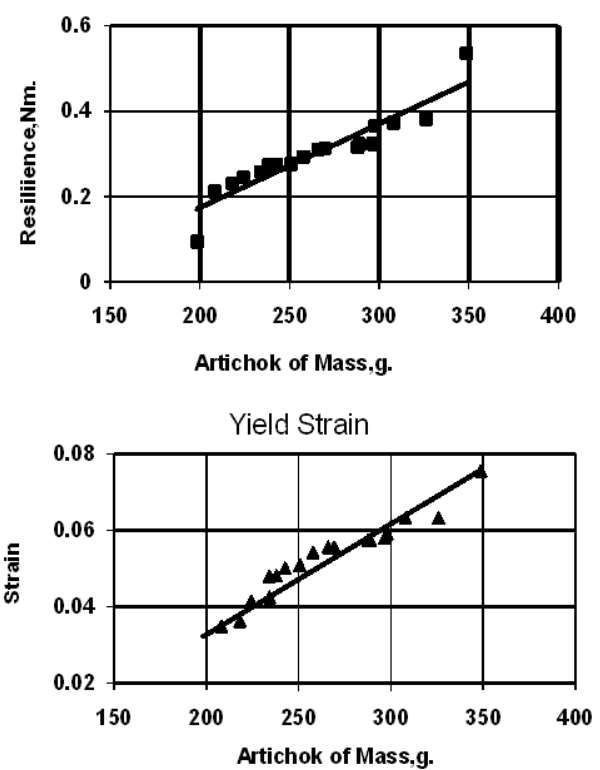
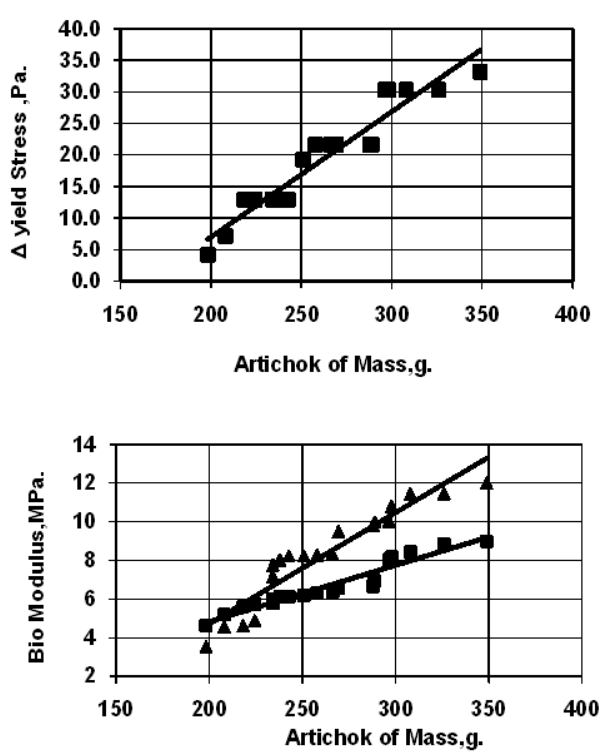

Dinitial Modulus,MPa. \Secondary,Modulus,MPa.

Figure (8) Mechanical properties at Yield Point of fresh Artichoke
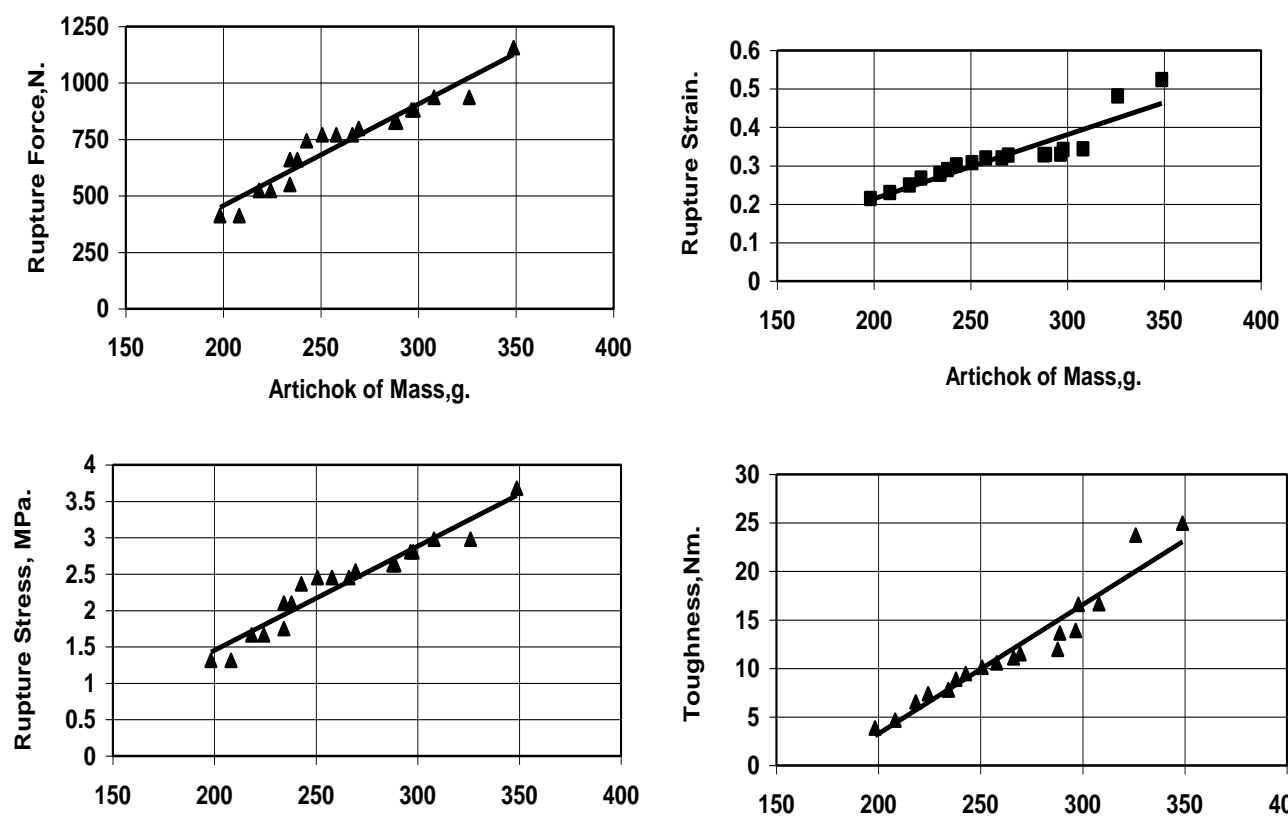

Artichok of Mass,g.

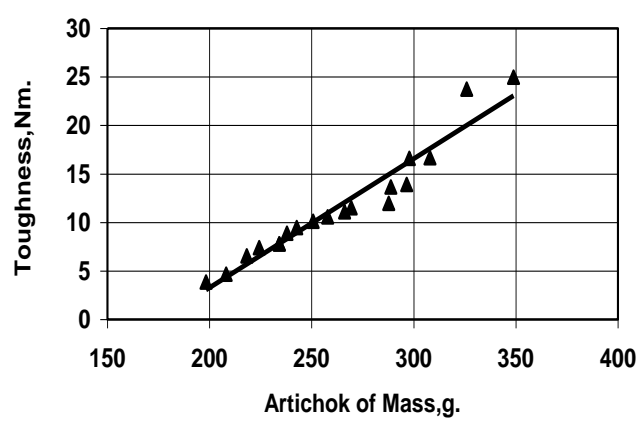

Figure (9) Mechanical properties at rupture Point of fresh Artichoke 


\section{CONCLUSION}

Physical characteristics and mechanical properties of Artichoke commodity is very necessary for handling, sorting, packaging, cold storage and in processing industries applications. The standard regulations for artichokes depend on concerning sizing and texture requirements at the export control stage. The artichoke should be sorted according to its maximum equatorial diameter as recommended.

This study reported some physical and mechanical properties of artichoke heads of the local artichoke cultivar (Balady) including equatorial diameter, top diameter, height, single head weight and volume, surface area, particle and bulk density, Spheresty, porosity, heads bio-modulus of elasticity, bio-yield stress, strain and energy, bio-rupture stress, strain and energy. The results showed that the artichoke head has average diameters from 46.03 to 112.26 . The results showed that there are a linear regression between average diameter, height, volume, and particle density with mass of fresh artichoke. The average diameter, height, volume were increased directly with mass of head fresh artichoke.

Force deformation test of fresh artichoke showed that the big of head artichoke masses have more strength than that for the small one. The results appear that yield stress, resilience, yield strain, initial modulus of elasticity and second modulus of elasticity incarcerates gradually with increasing mass of fresh artichoke . Rupture stress; rupture strain and toughness increases gradually with increasing mass of fresh artichoke.

These previous studied parameters are necessary for handling and storage. A potential possibility to sort the heads is by image processing, since the different head groups had different shape and projected area.

\section{REFERENCES}

Arcas L., A. J. Fernández (2007). Analysis of the artichoke trade. Available at: http://www.actahort.org/books/730/index.htm

Artichoke world production. 2002. Available at:

http://www.ers.usda.gov/Briefing/Vegetables/vegpdf/ArtichokeHigh.pdf Anderson, J., \& Garner, S. (1997). Phytoestrogens and human function. Nutrition Today, Vol. 32(6); Nov./Dec: p.232-239.

Brand N. (1990). Cynara scolamus L-the artichoke [translated from German].Z Phytother.1990;11:169-175. 
PROCESS ENGINEERING

http://www.swedish.org/110799.cfm

Carlo, F. (2001). The artichoke, symbolic vegetable of the Mediterranean. Available at

http://editore.slowfood.com/editore/riviste/slowark/EN/41/01_Atenderheart.pdf

Diane, B.; R. Dismukes ; J. Harwood ;A. Somwaru and G. Zepp, Coordinator (1995). Globe artichokes, an economic assessment of the feasibility of providing multiple-peril crop insurance.U.S. Department of Agriculture for the Consolidated Farm Service Agency, November 20, 1995.URL:

www.rma.usda.gov/pilots/feasible/PDF/artichok.pdf

FAO (2005), Food and Agricultural Organization of the United Nations. Statistical Database- Agriculture. Accessed July 2005.

URL: http://faostat.fao.org/faostat/collections?subset=agriculture

FAO (2012), http://faostat3.fao.org/home/index.html\#DOWNLOAD

Janick, J. and A. Whipkey (2002). Trends in new crops and new uses. 2002. Reprinted by Bharat P. Singh. Available at: www.hort.purdue.edu/newcrop/ncnu02/pdf/singh.pdf

kenanaonline, (2007). Artichokes. http://www.kenanaonline.com/page/health Lovre B, P. Slavko, and G. Smiljana (2000). Evaluation of Artichoke (Cynara scolymus L.) Cultivars in Three Growing Seasons. Journal of Agriculturae Conspectus Scientificus (ACS). 2000;Vol. 65 No.1. http://hrcak.srce.hr/index.php?lang=en\&show=clanak\&id_clanak_jezik=19259

Leela D. (1998). Anonymous. Artichoke Extract: Improves Digestion, Liver Function, and Cholesterol Levels. Natural Medicine Journal. Aug./Sept., 1998; Vol. 1, No. 7, pp. $22 \square 24$.

Leslie, T. (2005). The Healing Power of Rainforest Herbs. published in March 2005.URL: http://www.rain-tree.com/book2.htm

Moharram, Y. G.; Khalil, M. K. and Mostafa, M. M. (1981). Artichoke bracts (Cynara scolymus) as a source of protein. Monoufeia Journal of Agricultural Research. (1981) 4: 273-283.

Mohsenin, N. N. Physical Properties of Plant and Animal Materials, 3 ed. New York, USA: Gordon and Breach Science Publishers, 1986. Peter H. (1998). Artichokes the big apple. Available from: http://www.usasbe.org/knowledge/proceedings/1998/09-Hackbert.PDF 
Smits, P.J. (1989). Market development in western Europe in relation to vegetable diversification.. Available at:

http://www.actahort.org/books/242/242_2.htm

Stevens, C. and J. Kennan, (1999). 'Will Africa's participation in horticultural. chains survive liberalization.' IDS Working Paper No. 106. Sussex, U.K.: Available at:

www.webasa.org/Pubblicazioni/Gioe_2006_2.pdf

Tabei, M. (2007). Analysis of export demand for Egyptian artichoke. African crop Science Society, 2007, Vol. (8) pp: 1265 - 12

UC Davis (2007). Nutritional value of artichoke heads. Vegetable Research and Information Center. Home Vegetable Gardening. URL:

http://vric.ucdavis.edu/veginfo/commodity/garden/crops/artichoke.pdf U.N. (2003). United Nations, economic and social council, economic commission for Europe, working party on agricultural quality standards, report for the fifty ninth sessions, Geneva, 4 to 6 November 2003.

URAC (2005). Utilization Review Accreditation Commission; (health care accreditation \& certification). Artichoke. Available at:

http://healthlibrary.epnet.com/GetContent.aspx?token=8482e079-8512-

$47 \mathrm{c}-960 \mathrm{c}-\mathrm{a} 403 \mathrm{c} 77 \mathrm{a} 5 \mathrm{e} 4 \mathrm{c} \&$ chunkiid=21516 's.

William L. S., E. R. Vincent, H. S. Richard and W. H. Lange (2007). Artichoke, globe cynara scolymus. URL: http://vric.ucdavis.edu/ veginfo/commodity/artichoke/globeartichokes.pdf

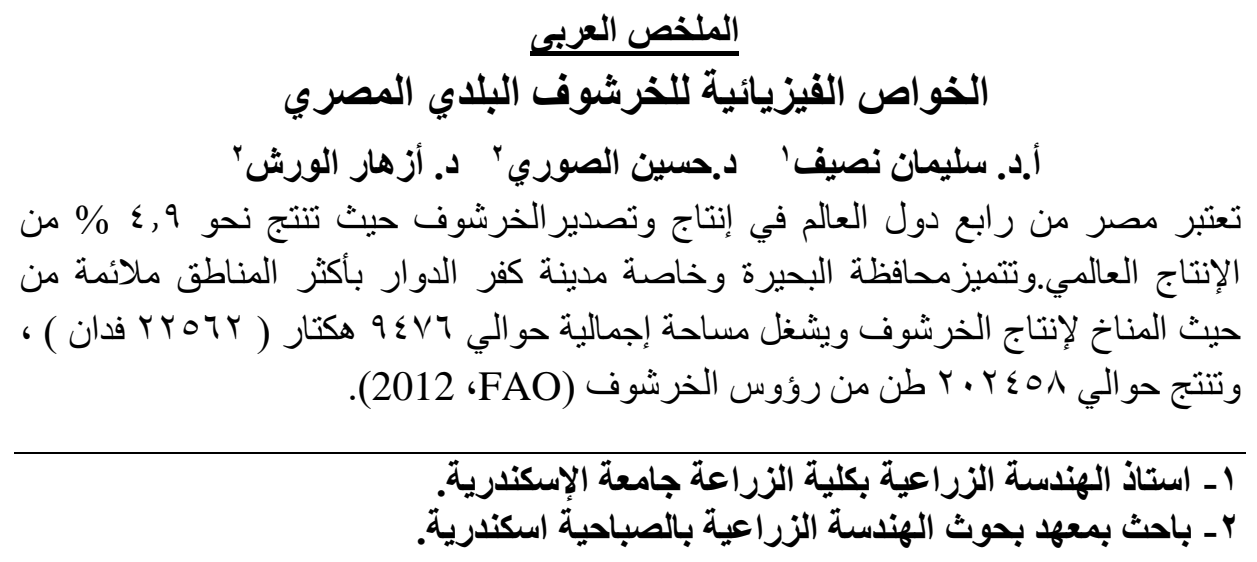


ونظر اً لزيادة الطلب العالمي الكبير علي الخرشوف المصري مما يتطلب معه الإهتمام بتوفير المو اصفات القياسية للخرشوف البلدي المصري و التي تشمل الخصائص الخضرية و الخواص اصل الطبيعية و الطرق المناسبة للتخزين المبرد وخصائص الطبخ. ونظر آ لعدم توفر المعلومات و البيانات بهذا الصدد فقد وجب الاهتمام بدر اسة الخصائص و الخو اص الطبيعية له لاستخدامها ولهيا كمعايير تصميمية فى عمليات التداول و الفرز و التعبئة و التغليف.

وفي هذا البحث تم دراسة بعض الخصائص والخواص الطبيعية لصنف الخرشوف المحلي

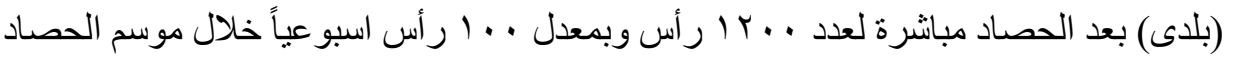

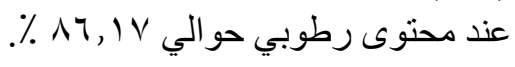

تضـنت الخصـائص و الخـو اص الطبيعيـة للبر عم قيـاس كل من الخصـائص البعديـة (القطرين

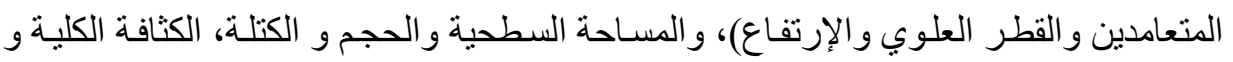

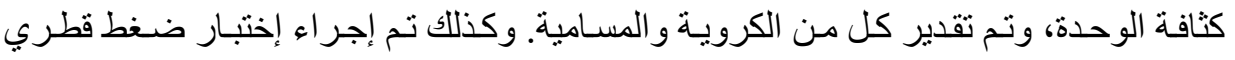

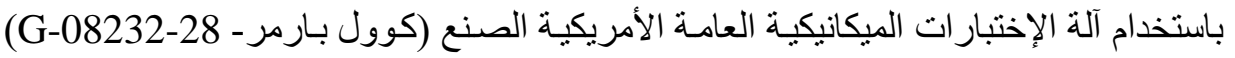

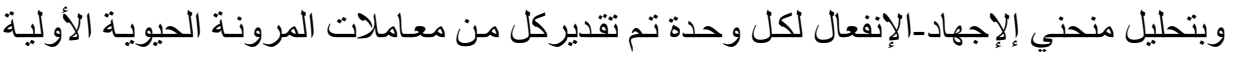

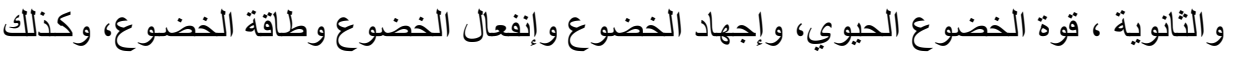

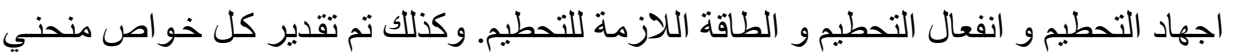

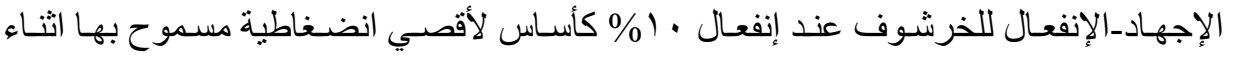
تداول وتخزين وتصنيع الخرشوف.

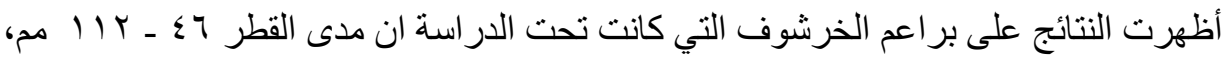

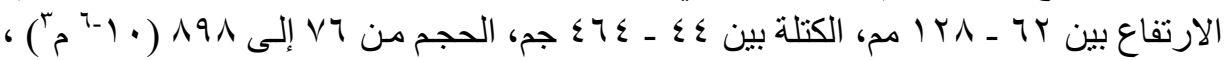

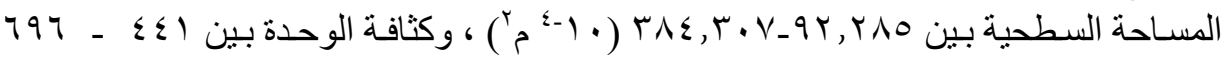

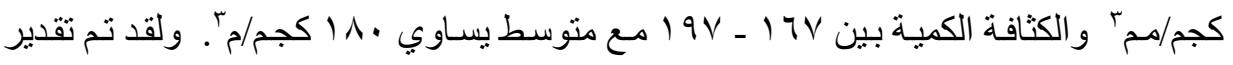

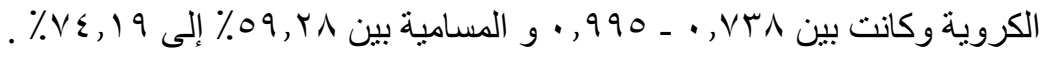

وكانت نتائج إختبار الضغط الميكانيكي القطري لبر اعم الخرشوف وذللك بتحليل منحني الإجهاد

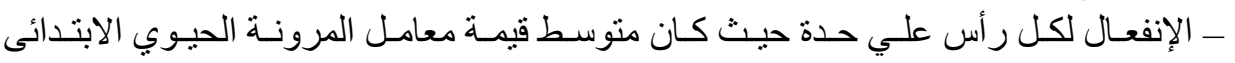

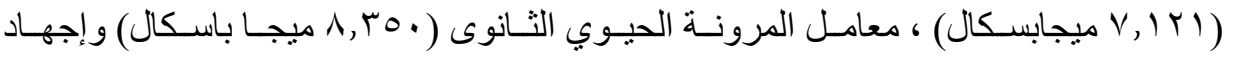

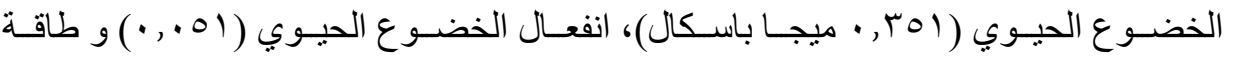

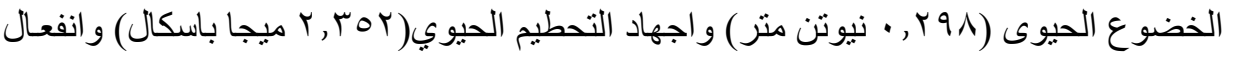

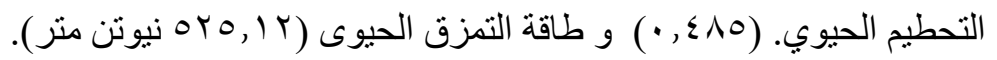

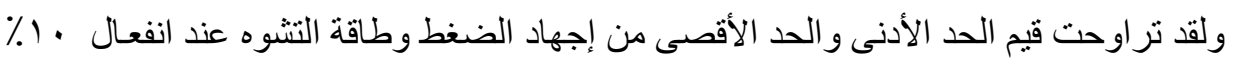

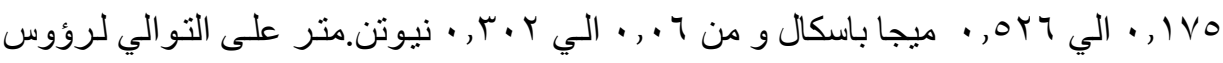
الخرشوف تحت الدراسة. 